MATÚŠ MATERNA, Ph.D. ${ }^{1}$

E-mail: matus.materna@fpedas.uniza.sk

BENEDIKT BADÁNIK, Assoc. Prof. ${ }^{1}$

E-mail: benedikt.badanik@fpedas.uniza.sk

(Corresponding author)

ALENA NOVÁK SEDLÁČKOVÁ, Assoc. Prof. ${ }^{1}$

E-mail: alena.sedlackova@fpedas.uniza.sk

ANDREA MATERNOVÁ, Ph.D. ${ }^{2}$

E-mail: andrea.galierikova@fpedas.uniza.sk

${ }^{1}$ Air Transport Department

Faculty of Operation and Economics of Transport

and Communications, University of Zilina

Univerzitna 1, 01026 Zilina, Slovak Republic

${ }^{2}$ Department of Water Transport

Faculty of Operation and Economics of Transport

and Communications, University of Zilina

Univerzitna 1, 01026 Zilina, Slovak Republic
Transport Economics

Original Scientific Paper

Submitted: 22 Apr. 2021

Accepted: 27 July 2021

DOI: $10.7307 /$ ptt.v33i5.3868

\title{
COMMERCIALISATION OF AIR NAVIGATION SERVICE PROVIDERS - EVIDENCE FROM EUROPE
}

\section{ABSTRACT}

This paper deals with the on-going process of commercialisation of air navigation service providers (ANSPs) with specific focus on Europe. First part offers overview of conducted research on their commercialisation and identifies two main external drivers for the emergence of commercialisation - liberalisation of national markets and demand for other ANS related services. Our research also proposes methodology for numerical assessment of the degree of commercialisation based on the ANSP's Commercialisation Index (ACI) and presents numerical evaluation of the ACI index of 35 European providers and proposes six different categories of providers reflecting different degree of their commercialisation. Results reveal that $63 \%$ of the European ANSPS show signs of commercialisation. On top of that, our outcomes prove that corporatisation cannot be considered a direct manifestation of commercialisation. Despite the most widely accepted view that corporatised providers are commercially active, the findings show that almost 40\% of corporatised European ANSPS are not commercially active. The paper also claims that ownership of subsidiaries and joint ventures is the most dominant demonstration of commercialisation. At the same time, our outcomes show that the provision and development of commercial services and products related to ANS are the most common commercial activities of the European ANSPS.

\section{KEYWORDS}

commercialisation; air navigation service providers; ANSPs; business model.

\section{INTRODUCTION}

Since the very beginnings of commercial air transport, the provision of ANS has been considered a monopoly sector in which individual ANSPs provided air navigation services on national monopolistic markets solely in the public interest. This situation comes from a historical precedent based on the 1944 Chicago Convention. In vast majority of countries, the legislative framework for provision of air navigation services protects national providers and it does not allow other entities to enter the national market for air navigation services. Such legislation has put ANSPs in a position of geographical monopoles with no direct competition in their national markets. Provision of air navigation services has only been liberalised in small number of countries and it has not affected the whole sector. However, commercialisation of individual ANSPs started to appear more frequently, especially in the last ten years. This is a radical departure from the old way of thinking of ANSPs, which has viewed additional commercial activities as burdens. Most authors dealing with this issue associate the commercialisation of air navigation service providers exclusively with their organisational and ownership structure and the application of management methods typical for the private sector. However, such a one-sided approach is insufficient due to the scale and complexity of the issue. The primary motivation for research on this issue is the lack of 
a comprehensive view of the commercialisation of ANSPs. Therefore, the aim of the paper is to outline new methodology for numerical assessment of the degree of commercialisation based on the ANSPs Commercialisation Index (ACI). This paper contributes to the literature by providing novel view on commercialisation of ANSPs, different from the one that associates the commercialisation of air navigation service providers exclusively with their organisational and ownership structure and the application of management methods typical for the private sector.

\section{LITERATURE REVIEW}

Majumdar [1] published one of the first scientific articles evaluating the commercialisation of ANSPs. The author identified commercialisation as separation of the organisational structure and management of ANSPs from the state-body structure. He identified Airways (national ANSP of New Zealand) as the first ANSP that was restructured to a commercial company based on commercial law, but the ownership remained public. Golaszewski [2] describes commercialisation similarly to Majumdar [1]. The author identified several ANSPs as commercialised (e.g. National Air Traffic Services (NATS), Deutsche Flugsicherung (DFS), etc.) based on their management and organisational structures. Goodliffe [3] deals with the new organisational and ownership model of NATS, which has undergone privatisation. However, the author clearly identified that "NATS gets commercial freedom to build a business within the current regulatory framework." Button and McDougall [4] identify the commercialisation of ANSPs as a change of organisational and ownership structures, from "state-like" to those typical for the private sector. However, the authors argue that the commercialisation of ANSPs needs to be based on a commercial public-private partnership or creation of subsidiaries using charges paid by airspace users. They also argue that commercialisation does not necessarily mean efforts of ANSPs to enter capital markets and their participation in public tenders for provision of various commercial services. Another important publication focused on the ANSPs commercialisation is the "McGill Report on Governance of Commercialised Air Navigation Service Providers" [5]. Not only does the study see commercialisation as a change in organisational and ownership structures (the cost-effectiveness and quality of services provided), it also sees it as a way to establish public-private partnerships (PPP). Steuer [6] supports the establishment of PPP by showing the example of NATS. He claims that "indicators do not support the fears, that many had, that even a partial privatisation would compromise the performance of ATC. This performance was good prior to the PPP and it has remained good". McDougall and Roberts [7] present commercialisation as a process that involves new ways of financing and managing organisational-ownership structures. However, access to capital markets is necessary for successful commercialisation, the authors say. The authors also claim that commercialised ANSPs demonstrate three main strengths: the ability to respond to customer requirements, the ability to make agile decisions, and the ability to act quickly. According to the authors, these characteristics lead to positive changes in operational and cost efficiency, time, and cost discipline in new projects and in continuous efforts to develop and implement new technologies to improve services. Jones and Guthrie [8] even divide the services provided by air navigation service providers into general services (service in public interest) and commercial, which are often focused on the next offer of commercial activities as supporting of the deployment of infrastructure, wind turbine, or installation of radar technologies $[9,10]$. According to the authors, commercialisation is one of the ways to modernise the provision of ANS.

Tomová [11-13] has covered the issue of commercialisation of ANSPs to a great extent. Tomová [11] mentions commercialised ANSPs as those applying private sector-specific management principles. However, she also describes commercialisation as the provision of ANS on a commercial basis. Tomová also divides product of ANSPs into core product (e.g. directly related to ANS) and supporting (augmented) product (related to Communication Navigation \& Surveillance (CNS), Aeronautical Information Service (AIS), and Search and Rescue Service (SAR)). She even identifies various models of competition of individual providers on the market with terminal and supporting services. Tomová [12] expands product categorisation further by two different approaches to provision of air navigation services. A classic approach to provision of air navigation services and commercial approach in which ANS are distinguished based on the degree of the regulation: services provided on domestic market (regulated provision) or services provided on a 
commercial (non-regulated) basis. The author also evaluates some ANSPs in terms of their revenues from commercial (non-regulated) activities and identifies their public statements regarding their commercial intentions. Tomová [13] also analyses NATS as a "two-business" ANSP, where she suggests that first business represents services in the domestic regulated market and the second represents commercial activities. Tomová, as one of the first authors, speaks about commercialisation as an activity directly connected to the orientation towards commercial forms of income. Bartoš \& Badánik [14] claim that European markets with ANS will be facing future competitive challenges mainly due to gradually increasing commercial trends. On the other hand, Dempsey-Brench and Volta [15] describe most European ANSPs as commercialised. Their conclusion is based on their opinion that commercialised provider is the one that applies the same forms of management and organisational/ownership structures as are applied in private sector. For authors, the degree of orientation towards commercial forms of business is not a degree of commercialisation. Buyle et al. [16] presents a typology of European ANSP business models focused on ANSP score of five factors, five business models groups: the traditional ANSPs, basic ANSPs, collaborating ANSPs, transitional ANSPs, innovators, and large professionals. Wirsamulia [17] explores commercialisation of Airnav Indonesia and shows that this trend is spreading worldwide, and claims: "Commercialisation of the air navigation service will provide a mutual benefit not only among stakeholders in the aviation industry, but also for aviation safety". Beside the outcomes of independent scientific research, there are also findings of international organisations engaged in the available research of commercialisation. International Civil Aviation Organisation (ICAO) [18] conducted a long-term series of case studies to identify the degree of commercialisation of air navigation service providers in 26 countries. However, this study does not evaluate commercialisation of air navigation service providers from the "development of commercial activities" point of view. It looks at their organisational and ownership structure. In this study, commercialised provider is the one whose organisational and ownership model is similar to the model used in private sector. International Air Transport Association (IATA) [19] has also produced a short document that covers a set of recommendations for the successful commercialisation of ANSPs. Unlike ICAO [18], IATA understands commercialisation not only as a change in organisational and ownership structures, but also as the orientation of air navigation service providers towards commercial revenues. However, IATA recommends that commercialisation should never lead to a conflict between public and commercial interests.

Literature review reveals two predominant views of commercialisation of ANSPs. First view describes the commercialisation of providers as a change in organisational and ownership structures and the application of management methods typical for the private sector. Many authors consider these changes very positive as they usually mean improved cost efficiency, operational performance, flexibility of management, and improved implementation of new technologies. The second view of commercialisation not only takes into account the existing changes in the organisational structure and management of providers, but also considers them as the tools that allow better and more flexible orientation to provision of service in public interest together with provision of other services on a commercial basis. Changes in the organisational and ownership structures of ANSPs (leading to improved cost-effectiveness, flexibility of management, and implementation of new technologies) are important drivers for the commercialisation of air navigation service providers.

\section{Liberalisation of national markets for air navigation services}

The Air Traffic Management (ATM) Policy Institute [20] suggests that there are several precedents for liberalisation of the sectors (that used to be considered monopolistic in the past). This includes sectors such as energy, telecommunications, rail transport and, last but not least, air transport. Benderli and Smith [21] argue that the past shows clear evidence that the liberalisation of monopoly network industries has brought significant improvements of the network services that were provided by monopolies. Therefore, the liberalisation of the ANS sector has relatively great potential for structural changes of the sector. Some ANSPs may see the liberalisation of the sector as a threat that could potentially lead to redundancies, reduced viability of some providers, and lower safety standards. In the past, there were similar concerns present with respect to the liberalisation of civil air transport, but most of them were deemed unnecessary. When 
compared to provision of services by monopolies, liberalisation of terminal navigation services has often led to significant reduction of the costs: USA $-74 \%$ [22], Spain $-50 \%$ [23], or Sweden $-30 \%$ [24]. However, the cost reduction did not represent any reduction in the quality or safety of the services provided [22]. The ATM Policy Institute [20] even says that the liberalisation of the industry has a positive impact on the safety and quality of ANS. The reason is that the provision of these services on a commercial basis has greater potential for introducing innovative technologies and maintaining high standards of the service. The liberalisation of national markets for navigation services is one of the main drivers for the commercialisation of ANSPs. Liberalised national markets with terminal services are one of the main opportunities for ANSPs to generate commercial revenue. The provision of these services on a commercial basis is not subject to the EU regulation. This fact emphasises the importance of these markets for individual providers, mainly because of their potential for the future development of commercial activities for which implementation of a liberalised legislative framework is required. At the time of writing, several providers are already providing their services on liberalised markets (e.g. AustroControl in Germany, FerroNATS (partnership between Ferrovial Servicios and NATS) in Spain, or DFS in the United Kingdom).

\section{Determinants of demand for additional ANS related services}

Demand for services, not directly related to the core ATM product, is another factor with an unquestionably doubtful positive impact on the commercialisation of ANSPs. There is a number of areas that individual providers can step into on a commercial basis. For example, calibration services, training services, consulting services, etc. Demand for supporting services arises mainly from the fact that outsourcing of these services is often a more rational and cost-effective solution than the provision of these services by individual ANSPs.

Provision of supporting ANS services on a commercial basis includes the provision of the following three basic services: CNS, Meteorological Service (MET), and Aeronautical Information Service (AIS). According to Regulation (EU) No. 391/2013 of 3 May 2013 on a common charging scheme for air navigation services, the Search and Rescue Service (SAR) may not be the subject of commercialisation. There are several cases where individual ANSPs provide supporting services on a commercial basis (e.g. EAD APAC Group, a joint venture between Airways New Zealand and Enaire, established to provide AIS services in the Pacific region or Naviar providing AIS and CNS services for Greenland).

Another scheme for provision of supporting services are services associated with ANS. There is a number of areas that individual providers (for which outsourcing of these services is more advantageous) are stepping into on a commercial basis in response to the demand for provision of such services by other ANSPs or companies. The most sought-after supporting services that providers demand for, with a view to provide better ANS service, are various types of consulting and advisory services. Consulting and advisory services usually cover a variety of areas, e.g. improved efficiency of navigation services and airspace management (e.g. NATS in Japan since 2017) or airspace design services (e.g. NATS for Dubai Al Maktoum Airport or NATS for Ninoy Aquino Airport). On top of that, some providers demand for provision of training services. Real life examples show individual ANSPs providing professional trainings for ATCOs or pseudo-pilots for another ANSP (Air Navigation Services of the Czech Republic (ANS CR) provided Air Traffic Controller (ATCOs) training services for Bosnia and Herzegovina Air Navigation Services Agency (BHANSA), Malta Air Traffic Services (MATS) and Norway's Air Navigation Service Provider (Avinor) or DFS, which provided training for NATS through its subsidiary Air Navigation Solutions). Also, technical supporting services such as the maintenance of existing infrastructure or the deployment of new infrastructure are frequently offered by individual providers (e.g. NATS offers wide range of technical services like commercial installation of radar technologies at airports or the deployment of wind turbine together with all supporting services).

Outsourcing of certain activities (that are necessary for the safe and smooth provision of ANS) or activities related to the provision of ANS is an important driver of commercialisation of ANSPs. Provision of additional supporting services by ANSPs (commercialisation of ANSPs) usually does not require additional implementation of a liberalised legislative framework. It makes the whole process of commercialisation of ANSPs significantly simpler (compared to liberalisation of ANSPs) and opens new possibilities for commercial activities of individual ANS providers. 


\section{METHODOLOGY}

This research is based on definition of commercialisation outlined by Materna \& Galieriková [25] determining means and scope of commercialisation of ANPSs. The definition is based on linguistic analysis of several common definitions of the "commercialisation" and word-count statistics of these definitions. We have developed a new general definition of commercialisation and repurposed it to make it specific for the process of commercialisation of ANSPs; "Commercialisation of air navigation service providers is a process of supplying commercial services and products into various aviation markets, using innovative forms of management for the purpose of creating additional revenues."

In our previous publications $[25,26]$, we have also published partial results of the research on commercialisation of ANSPs and introduced two new categorisations of ANPSs. First categorisation [25] is based on simple textual analysis of the term commercialisation by the use of our own definition. This research categorised ANSPs into five basic categories representing their different commercial interests: (1) non-commercialised ANSPs; (2) non-commercially cooperating ANSPs; (3) commercially cooperating ANSPs; (4) commercially focused ANSPs; (5) commercial ANSPs. Later on, Materna [26] categorised ANSPs business models into three distinct categories reflecting individual nature of operations and management of each ANSP: (1) legacy (historical) business model; (2) indifferent business model; (3) commercial business model.

Also, Materna et al. [27] introduced textual framework for direct comparison of commercialised ANPSs based on their organisational and ownership structure. The framework takes into account the following parameters: commercial (non-regulated) basis for the provision of ANS, provision of commercial (ANS related) services, provision of commercial services (non-related to ANS), number of subsidiaries and joint-ventures owned or coowned by a particular ANSP, public declaration of commercial activities, etc.

As indicated earlier in this section, this research is based on the definition of the term commercialisation that we have developed in previous research. This definition helped to identify fundamental parameters of more complex research of commercialisation of European ANSPs by focusing on the following key areas of their businesses and business models:
1) Provision of ANS on a commercial (non-regulated) basis

2) Provision of commercial services and products (ANS related)

3) Provision of commercial services and products (Non-related to ANS)

4) Commercial research and deployment of innovative technologies

5) Public declaration of commercial activities

6) Ownership of subsidiaries and/or joint ventures.

\subsection{Commercialisation of ANSPs - numerical evaluation}

In this research, numerical evaluation (model) of commercialisation of individual ANSPs is represented by the so called ANSPs Commercialisation Index $\left(\mathrm{A}_{\mathrm{CI}}\right) \cdot \mathrm{A}_{\mathrm{CI}}$ is defined as the ratio of the sums of all values assigned to the attributes (based on proposed key areas) and the total number of attributes entering the calculation of the index. $\mathrm{A}_{\mathrm{CI}}$ can reach values on a closed interval $[0 ; 1]$. 0 represents the minimum value of the index (ANSPs with no signs of commercialisation) and 1 represents its maximum (ANSP with highest degree of commercialisation). The model uses the following formula for the calculation of the $\mathrm{A}_{\mathrm{CI}}$ value:

$A_{C I}=\frac{\sum \text { values of all attributes }}{\text { number of values }} ; A_{C I}=[0,1]$

ANSPs Commercialisation Index is taking into account four different areas of commercial activities and products conducted (offered) by ANSPs (Attributes \#1 - \#4). On top of that, the index also includes commercial activities of individual ANSPs as they are declared by them (attribute \#5) and ownership of subsidiaries and/or joint ventures (attribute \#6). We have predefined three basic criteria and their corresponding values for all attributes outlined in Table 1.

Attribute \#1 - "Provision of ANS on a commercial (non-regulated) basis" represents a situation in which ANSP provides terminal or en-route ANS on deregulated (liberalised) markets on a commercial basis (e.g. DFS providing terminal services on several regional airports in Germany and in the UK). Attribute \#2 - "Provision of commercial services and products (ANS related)" evaluates a situation in which ANSP provides ANS related commercial services or offers products that are not directly linked to ATM (e.g. Austrocontrol provides commercial calibration services or ANS CR provides ATCO training for BHANSA). Attribute \#3 - "Provision 
Materna M, Badánik B, et al. Commercialisation of Air Navigation Service Providers - Evidence from Europe

Table 1 -Attributes criteria and assigned values

\begin{tabular}{|c|c|c|c|c|c|}
\hline & & & 0 & 0.5 & 1 \\
\hline \multirow{6}{*}{ 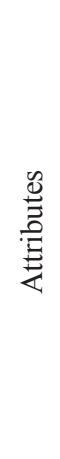 } & $\# 1$ & Provision of ANS on a commercial (non-regulated) basis & No & $\begin{array}{c}\text { Yes } \\
\text { (national market only) }\end{array}$ & $\begin{array}{c}\text { Yes } \\
\text { (internationally) }\end{array}$ \\
\hline & $\# 2$ & $\begin{array}{l}\text { Provision of commercial services and products (ANS } \\
\text { related) }\end{array}$ & No & $\begin{array}{c}\text { Yes } \\
\text { (national market only) }\end{array}$ & $\begin{array}{c}\text { Yes } \\
\text { (internationally) }\end{array}$ \\
\hline & $\# 3$ & Provision of commercial services and products (Other) & No & $\begin{array}{c}\text { Yes } \\
\text { (national market only) }\end{array}$ & $\begin{array}{c}\text { Yes } \\
\text { (internationally) }\end{array}$ \\
\hline & $\# 4$ & $\begin{array}{l}\text { Commercial research and deployment of innovative } \\
\text { technologies }\end{array}$ & No & $\begin{array}{l}\text { Yes (national market } \\
\text { only) }\end{array}$ & $\begin{array}{c}\text { Yes } \\
\text { (internationally) }\end{array}$ \\
\hline & $\# 5$ & Public declaration of commercial activities & No & Indirectly & Yes \\
\hline & \#6 & Ownership of subsidiaries and/or joint ventures & No & Non-commercial only & Commercial \\
\hline
\end{tabular}

of commercial services (other)" evaluates the provision of other commercial services that are not linked to ANS (e.g. DFS operates a commercial car park in Bremen). Attribute \#4 - "Commercial research and deployment of innovative technologies" describes the provision of commercial research and development of innovative technologies (e.g. Hungarian Air Navigation Services Provider (Hungarocontrol's Virtual Tower)). The values of these attributes (\#1\#4) depend on the markets in which the services are provided. 0 represents a situation in which the ANSP does not provide services and /or offer products on a commercial basis in the market. Attribute value 0.5 represents a situation in which the given commercial activities and products are provided by individual ANSP in a national market. Value $1 \mathrm{ex}-$ presses the situation in which the provision of commercial services and products has an international nature. Orientation of ANSPs towards international markets helps to reach a higher degree of their commercialisation. This is supported by the general definition of the term commercialisation [25], which claims that: "Commercialisation is a process of supplying commercial product(s) and activities (services) into new markets with an implementation of innovative management and policies to generate revenue."

If we were to quantify the degree of commercialisation of various ANSPs, one needs to look at the degree of declared involvement of individual ANSPs in commercial activities (Attribute \#5 - "Public declaration of commercial activities"). Value 0 (of the Attribute \#5) represents situation in which the individual provider does not declare any form of commercial activities (supply of products or provision of services). The only source where ANSPs declare their involvement in any kind of commercial activities is either their annual report or press release announcing the start of (commercial) cooperation (e.g. ANS CR). The value 0.5 represents those providers who are marginally or non-directly involved in conducting commercial activities (e.g. DFS), although they publicly talk about the provision of some "other than usual" services (such as navigation services on deregulated markets). Value 1 (of the Attribute \#5) represents the situation in which ANSPs clearly declare provision of commercial services and products as a part of their portfolio (e.g. NATS or Swedish Air Navigation Services Provider (LFV)). ANSPs usually provide detailed information about the areas and the scope of commercial activities they are involved in, including information on finished, ongoing, and upcoming projects. They also provide contact details for potential customers in various areas of their commercial activities.

Attribute \#6 - "Ownership of subsidiaries and/or joint ventures companies" evaluates ANSPs by ownership of subsidiaries and/or joint ventures. Value 0 represents a situation in which ANSP does not own a subsidiary and/or does not co-own a joint-venture company. Attribute \#6 reaches value 0.5 if individual ANSP does not have a subsidiary or a joint-venture or if the ANSP owns/co-owns a subsidiary/joint venture for non-commercial purposes (e.g. Slovak Air Navigation Services Provider (LPS SR) co-owns the Functional Airspace Block Central Europe (FAB CE) Aviation Services (the research joint-venture) with several other ANSPs.) If ANSP owns/co-owns joint-venture or subsidiary for commercial purposes, value of attribute \#6 is 1 (e.g. NATS owns or co-owns 16 subsidiaries and joint-ventures involved in a number of various commercial activities). Values of this attribute are also based on our own general definition, suggesting that the commercialisation is defined as "implementation of innovative management and policies to generate revenue". 


\section{RESULTS}

ANSPs Commercialisation Index $\left(\mathrm{A}_{\mathrm{CI}}\right)$ makes it possible to compare the extent of commercialisation of all European ANSPs. Table 2 shows current values of the $\mathrm{A}_{\mathrm{CI}}$ index, organisational structure and total number of subsidiaries and joint ventures of all European ANSPs.

The results suggest that almost $63 \%$ of all European ANSPs show signs of commercialisation, with the average value of $\mathrm{A}_{\mathrm{CI}} 0.3\left(\mathrm{~A}_{\mathrm{CI}} 0.48\right.$ is the average for those ANSPs with signs of commercialisation).

It is also possible to recognise the most and least common attributes of commercialisation. The least common attribute with its average value of 0.11 (average of 0.18 for ANSPs with signs of commercialisation) is Attribute \#1 - "Provision of ANS on a commercial (non-regulated) basis". This is possibly caused by the current state of deregulation (liberalisation) of ANS legislative framework across Europe. Only four European countries (United Kingdom in 1985, Germany in 2006, Spain in 2009, and Sweden in 2010) have introduced a partially de-regulated legislative framework on their national ANS markets with terminal navigation services which means only a limited number of possibilities for ANSPs to compete in provision of such services in a mostly heavy regulated and monopolistic national market segment.

Second least common attribute with average values 0.2 (all ANSPs) and 0.32, respectively (average value of commercialised ANSPs) is Attribute \#3 - "Provision of commercial service non-related to ANS." This fact can be explained by the previous nature of ANSPs operations. They used to be monopolistic subjects focusing on ANS related activities only. Providing commercial activities requires strong orientation of organisational culture towards commercial form of income, which is currently exercised by only a few European ANSPs. It is possible that ANSPs introducing commercial activities into their portfolio will firstly focus on ANS related products, rather than completely new (ANS non-related) activities.

The most common commercialisation attribute with average value of $0.47(0.75)$ is an Attribute \#6 - "Ownership of subsidiaries and/or joint ventures". This attribute clearly indicates the trend, that almost every ANSP conducting commercial forms of business is doing that by the use of its own subsidiaries and joint-venture companies (only Croatia Control, Serbia and Montenegro Air Traffic Services (SMATSA), Polish Air Navigation Services Agency (PANSA) and Direction des Services de la Navigation Aérienne, the French Air Navigation Services Provider (DSNA) are conducting commercial activities solely within their organisational structures).

The second and third most common attributes of commercialisation of ANSPs are Attribute \#2 - "Provision of commercial services and products (ANS related)" with the average value of 0.37 (0.59) and Attribute \#4 - "Commercial research and deployment of innovative technologies" with the average value of $0.36(0.57)$. These values indicate that ANSPs conducing commercial business tend to keep their focus on ANS related commercial activities rather than entering completely different markets.

\section{DISCUSSION}

Based on the results, it is possible to propose a new classification of air navigation service providers business models, discuss the link between corporatisation and commercialisation, and compare the level of commercial development to airspace size.

\subsection{Re-categorisation of ANSPs}

$\mathrm{A}_{\mathrm{CI}}$ values (presented in Chapter 3) help to compare the extent to which particular ANSPs are commercialised and to understand the differences between individual categories of ANSPs. This part of the paper presents an update of the categorisation of ANSPs introduced by Materna \& Galieriková [25]. It is based on the $\mathrm{A}_{\mathrm{CI}}$ values and introduces more precise categories of commercialised ANSPs (compared to previous categorisation):

1) Non-commercialised ANSPs represent almost $37 \%$ of European ANSPs $\left(\mathrm{A}_{\mathrm{CI}}=0\right)$. These providers are not involved in any commercial activities and they are not even interested in being involved.

2) Non-commercially cooperating ANSPs represent $9 \%$ of European ANSPs $\left(\mathrm{A}_{\mathrm{CI}}<0.1\right)$. Table 2 indicates that these providers (LPS, Croatia Control, and Slovenia Control) do not conduct any kind of commercial activities. They only own or co-own non-commercially oriented companies. The three providers co-own the non-commercial joint venture FAB CE Aviation Services Ltd. 
Materna M, Badánik B, et al. Commercialisation of Air Navigation Service Providers - Evidence from Europe

Table 2 - Commercialisation Index $\left(A_{C}\right)$, organisational structures and the number of subsidiaries and joint ventures of European ANSPS

\begin{tabular}{|c|c|c|c|c|c|c|c|c|c|c|}
\hline \multicolumn{4}{|c|}{ Basic information } & \multicolumn{7}{|c|}{$\mathrm{A}_{\mathrm{CI}}$ data and values } \\
\hline ANSP & Country & $\begin{array}{l}\text { Organisational } \\
\text { structure }\end{array}$ & $\begin{array}{c}\text { Number of } \\
\text { subsidiaries / } \\
\text { joint ventures }\end{array}$ & $\begin{array}{l}\text { Attribute } \\
\quad \# 1\end{array}$ & $\begin{array}{l}\text { Attribute } \\
\quad \# 2\end{array}$ & $\begin{array}{l}\text { Attribute } \\
\quad \# 3\end{array}$ & $\begin{array}{l}\text { Attribute } \\
\quad \# 4\end{array}$ & $\begin{array}{l}\text { Attribute } \\
\quad \# 5\end{array}$ & $\begin{array}{l}\text { Attribute } \\
\quad \# 6\end{array}$ & $\underset{\mathrm{CI}}{\mathrm{A}_{\mathrm{CI}}}$ \\
\hline DFS & Germany & $\begin{array}{c}\text { Limited liability } \\
\text { company }\end{array}$ & $7 / 8$ & 1 & 1 & 1 & 1 & 0.5 & 1 & 0.92 \\
\hline ENAIRE & Spain & State enterprise & $1 / 16$ & 0.5 & 1 & 1 & 1 & 1 & 1 & 0.92 \\
\hline NATS & UK & $\begin{array}{l}\text { Joint stock } \\
\text { company }\end{array}$ & $10 / 6$ & 1 & 1 & 0.5 & 1 & 1 & 1 & 0.92 \\
\hline LFV & Sweden & State enterprise & $3 / 4$ & 0.5 & 1 & 0 & 1 & 1 & 1 & 0.75 \\
\hline ENAV & Italy & $\begin{array}{l}\text { Joint stock } \\
\text { company }\end{array}$ & $3 / 2$ & 0 & 0 & 1 & 1 & 1 & 1 & 0.67 \\
\hline IAA & Ireland & $\begin{array}{l}\text { Joint stock } \\
\text { company }\end{array}$ & $1 / 3$ & 0 & 1 & 0 & 1 & 1 & 1 & 0.67 \\
\hline Skyguide & Switzerland & $\begin{array}{l}\text { Joint stock } \\
\text { company }\end{array}$ & $2 / 3$ & 0 & 1 & 0.5 & 1 & 0.5 & 1 & 0.67 \\
\hline $\begin{array}{l}\text { Austro } \\
\text { Control }\end{array}$ & Austria & $\begin{array}{c}\text { Limited liability } \\
\text { company }\end{array}$ & $2 / 2$ & 1 & 1 & 0 & 0 & 0.5 & 1 & 0.58 \\
\hline Avinor & Norway & $\begin{array}{l}\text { Joint stock } \\
\text { company }\end{array}$ & $3 / 0$ & 0 & 1 & 0 & 0.5 & 0.5 & 1 & 0.50 \\
\hline DSNA & France & $\begin{array}{c}\text { Part of state } \\
\text { structures }\end{array}$ & 0 & 0 & 1 & 0 & 1 & 1 & 0 & 0.50 \\
\hline $\begin{array}{c}\text { Hungaro- } \\
\text { Control }\end{array}$ & Hungary & State enterprise & $0 / 2$ & 0 & 0.5 & 0 & 1 & 0.5 & 1 & 0.50 \\
\hline PANSA & Poland & $\begin{array}{c}\text { Part of state } \\
\text { structures }\end{array}$ & 0 & 0 & 1 & 0 & 1 & 1 & 0 & 0.50 \\
\hline ANS CR & $\begin{array}{l}\text { Czech Re- } \\
\text { public }\end{array}$ & State enterprise & $2 / 1$ & 0 & 1 & 0.5 & 0 & 0 & 1 & 0.42 \\
\hline Naviair & Denmark & State enterprise & $1 / 3$ & 0 & 1 & 0 & 0 & 0.5 & 1 & 0.42 \\
\hline $\begin{array}{l}\text { NAV Portu- } \\
\text { gal }\end{array}$ & Portugal & State enterprise & $0 / 1$ & 0 & 0 & 0 & 1 & 0 & 1 & 0.33 \\
\hline SkyEyes & Belgium & State enterprise & $0 / 1$ & 0 & 0 & 0 & 1 & 0 & 1 & 0.33 \\
\hline Albcontrol & Albania & $\begin{array}{l}\text { Joint stock } \\
\text { company }\end{array}$ & $0 / 1$ & 0 & 0 & 1 & 0 & 0 & 1 & 0.33 \\
\hline SMATSA & Serbia & Public joint-venture & 0 & 0 & 0 & 1 & 0 & 0.5 & 0 & 0.25 \\
\hline EANS & Estonia & $\begin{array}{c}\text { Joint stock } \\
\text { company }\end{array}$ & 0 & 0 & 0.5 & 0.5 & 0 & 0 & 0 & 0.17 \\
\hline $\begin{array}{l}\text { Croatia } \\
\text { Control }\end{array}$ & Croatia & $\begin{array}{l}\text { Joint stock } \\
\text { company }\end{array}$ & $0 / 1$ & 0 & 0 & 0 & 0 & 0 & 0.5 & 0.08 \\
\hline LPS & Slovakia & State enterprise & $0 / 1$ & 0 & 0 & 0 & 0 & 0 & 0.5 & 0.08 \\
\hline $\begin{array}{c}\text { Slovenia } \\
\text { Control }\end{array}$ & Slovenia & State enterprise & $0 / 1$ & 0 & 0 & 0 & 0 & 0 & 0.5 & 0.08 \\
\hline $\begin{array}{c}\text { ANS } \\
\text { Finland }\end{array}$ & Finland & State enterprise & 0 & 0 & 0 & 0 & 0 & 0 & 0 & 0.00 \\
\hline ARMATS & Armenia & $\begin{array}{c}\text { Joint stock } \\
\text { company }\end{array}$ & 0 & 0 & 0 & 0 & 0 & 0 & 0 & 0.00 \\
\hline BULATSA & Bulgaria & State enterprise & 0 & 0 & 0 & 0 & 0 & 0 & 0 & 0.00 \\
\hline DHMI & Turkey & State enterprise & 0 & 0 & 0 & 0 & 0 & 0 & 0 & 0.00 \\
\hline HCAA & Greece & $\begin{array}{c}\text { Part of state } \\
\text { structures }\end{array}$ & 0 & 0 & 0 & 0 & 0 & 0 & 0 & 0.00 \\
\hline LGS & Lithuania & $\begin{array}{l}\text { Joint stock } \\
\text { company }\end{array}$ & 0 & 0 & 0 & 0 & 0 & 0 & 0 & 0.00 \\
\hline LVNL & Netherlands & $\begin{array}{c}\text { Independent } \\
\text { administrative unit }\end{array}$ & 0 & 0 & 0 & 0 & 0 & 0 & 0 & 0.00 \\
\hline MATS & Malta & $\begin{array}{c}\text { Joint stock } \\
\text { company }\end{array}$ & 0 & 0 & 0 & 0 & 0 & 0 & 0 & 0.00 \\
\hline M-Nav & Macedonia & $\begin{array}{c}\text { Joint stock } \\
\text { company }\end{array}$ & 0 & 0 & 0 & 0 & 0 & 0 & 0 & 0.00 \\
\hline MoldATSA & Moldova & State enterprise & 0 & 0 & 0 & 0 & 0 & 0 & 0 & 0.00 \\
\hline $\begin{array}{l}\text { Oro Navi- } \\
\text { gacija }\end{array}$ & Lithuania & State enterprise & 0 & 0 & 0 & 0 & 0 & 0 & 0 & 0.00 \\
\hline ROMATSA & Romania & State enterprise & 0 & 0 & 0 & 0 & 0 & 0 & 0 & 0.00 \\
\hline UkSATSE & Ukraine & State enterprise & 0 & 0 & 0 & 0 & 0 & 0 & 0 & 0.00 \\
\hline \multicolumn{4}{|c|}{ Average values of all ANSPs } & 0.11 & 0.37 & 0.20 & 0.36 & 0.3 & 0.47 & 0.3 \\
\hline \multicolumn{4}{|c|}{ Average values of ANSPs with signs of commercialisation } & 0.18 & 0.59 & 0.32 & 0.57 & 0.48 & 0.75 & 0.48 \\
\hline
\end{tabular}


This joint venture was established in order to increase the operational and cost efficiency of provision of ANS in the FAB CE.

3) Commercially underdeveloped ANSPs is the category representing ANSPs that are involved in a limited number of commercial activities, mainly in their national markets. All the activities are covered under their own organisational structure. $\mathrm{A}_{\mathrm{CI}}$ value of this category falls between 0.1 and 0.25 . The data indicate that Estonian Air Navigation Services (EANS) and SMATSA fall into this category (6\% of all European ANSPs). Both providers are involved in provision of professional training on a commercial basis.

4) Commercially cooperating ANSPs is the category represented by the Portuguese Air Navigation Services Provider (NAV Portugal), Belgian Air Navigation Services Provider (SkyEyes), and the Air Navigation Services of Albania (Albcontrol). The $\mathrm{A}_{\mathrm{CI}}$ value of the category is 0.33 . Each of the three providers is involved in one single type of commercial activity (commercial co-ownership of joint venture). In 2018, Albcontrol, Turkish Airlines, and the Albanian investment company MDN Investment formed a joint venture that operates Albania airlines. SkyEyes entered into a joint venture agreement with the private company Entry Point North. The newly formed company has set up a training centre that provides training for the Luxembourg ANSP ANA Lux and for other aviation personnel on a commercial basis.

5) Commercially focused ANSPs represent 31\% of all European ANSPs with $\mathrm{A}_{\mathrm{CI}}$ values falling between 0.4 and 0.8 . Commercially oriented ANSPs are focusing on international markets. The category represents ANSPs that are focusing on several forms of commercial activities, conducted by either their subsidiaries or joint ventures (DSNA and PANSA are the only exceptions from this category. Both ANSPs provide various commercial services under their own organisational structures). Most activities of commercially oriented ANSPs are linked to training (e.g. ANS CR, Austrian Air Navigation Services Provider (Austrocontrol)), flight calibration services (e.g. Swiss ANSP (Skyguide), ANS CR), research, development, and innovation (e.g. Hungarontrol and Avinor with their Virtual Tower technology or PANSA with its innovative tools for the use of UAVs in ATM). ANSPs in this category do not provide ANS on commercial basis in liberalised markets. The only exception in the category is Austrocontrol providing terminal services at several small airports in Germany.

6) Commercial ANSPs represent $9 \%$ of ANSPs. The $\mathrm{A}_{\mathrm{CI}}$ values of this category are higher than 0.8. These ANSPs are "top" in terms of commercialisation. All three ANSPs in this category (DFS, NATS, and the Spanish ANSP (ENAIRE)) have developed their commercial activities to a great extent. They offer a wide range of services and products in all defined commercial categories (they even provide services non-related to ANS, e.g. DFS operates a car park on a commercial basis, ENAIRE operate airports, NATS offers training of personnel that is not related to ATM). There are some other similarities between individual providers in this category: all ANSPs are providing commercial ANS services in deregulated markets, their own national markets have undergone the process of partial liberalisation. All three ANSPs co-own the biggest number of subsidiaries and joint-venture companies and they are focusing on penetration in international markets.

\subsection{Corporatisation vs. Commercialisation}

Table 2 shows that the majority (89\%) of European air navigation service providers have undergone a process of corporatisation. This means that their organisational structures have been disconnected from the state authorities (such as ministries or aviation authorities) and ANSPs started to act as "private-like" entities under various organisational structures: state enterprises, joint-stock companies, or limited liability companies. However, almost $40 \%$ of European corporatised providers show no signs of commercial orientation. On the other hand, most providers with commercial activities (91\%) have been corporatised. This means that corporatisation cannot automatically be considered an orientation of the provider towards provision of commercial services and products (as incorrectly interpreted by many authors dealing with the issue). The authors claim, de jure, commercialisation. On the other hand, ANSPs with commercial activities are frequently entities that are, from organisational point of view, similar to private commercial organisations (de facto commercialisation). 


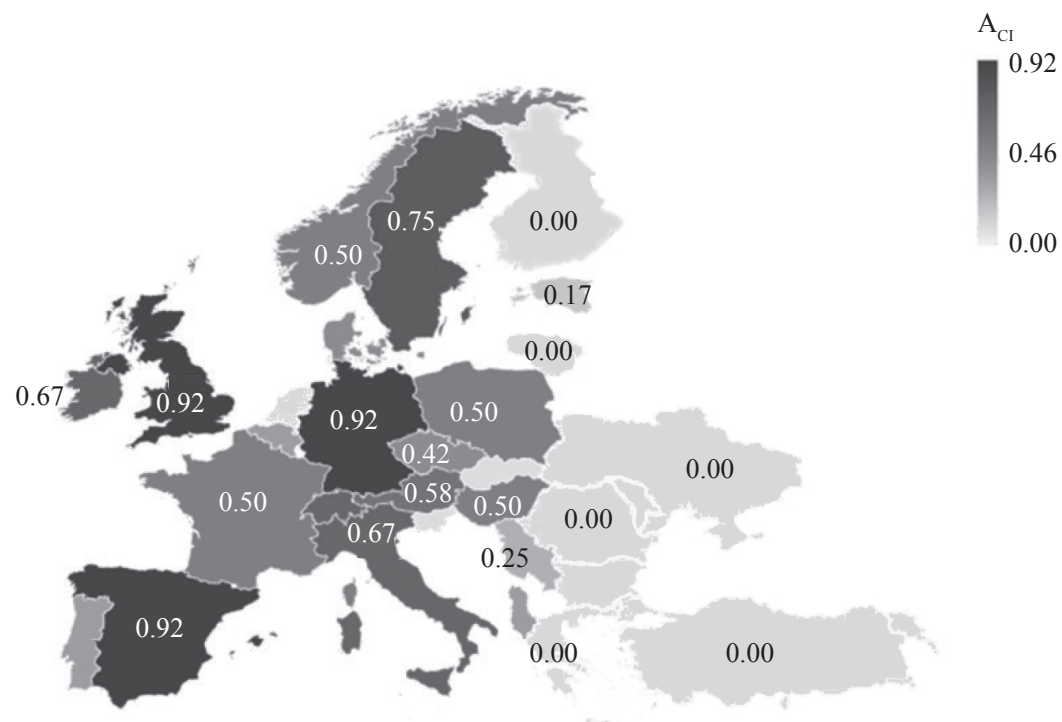

Figure 1 - Visual representation of $A_{C I}$ values in Europe

\subsection{Airspace size}

Figure 1 suggests that the larger size of the airspace does not necessarily mean higher degree of commercialisation of particular ANSP. For instance, the $\mathrm{A}_{\mathrm{CI}}$ of NATS, managing $242,495 \mathrm{~km}^{2}$ of airspace is 0.92 , which is much higher than the $\mathrm{A}_{\mathrm{CI}}$ of ANS Finland (0.00), managing $338,455 \mathrm{~km}^{2}$ of airspace, much larger airspace that the airspace of the UK. In addition, the $\mathrm{A}_{\mathrm{CI}}$ of NATS, managing $242,495 \mathrm{~km}^{2}$ of airspace is 0.92 , which is equal to $\mathrm{A}_{\mathrm{CI}}$ of ENAIRE (0.92), managing a much larger airspace of $505,990 \mathrm{~km}^{2}$. In a global picture, there is evident difference between Western and Eastern Europe. The fact that Western European countries are more economically developed implies that the size and economic power of their domestic market have a positive impact on commercialisation of their national ANSPs.

\section{CONCLUSION}

Nowadays, there is an increased number of ANSPs moving towards commercialisation (this trend is evident in Europe and in other world regions like Canada or New Zealand).

More than $63 \%$ of all European ANSPs show signs of commercialisation. Despite the fact that the majority of European ANSPs have undergone process of corporatisation ( $89 \%$ ), only $61 \%$ of them are showing signs of commercialisation. Therefore, corporatisation cannot automatically be considered a sign of commercialisation.
ANSPs that provide commercial activities usually use the following two forms: ownership or co-ownership of subsidiaries or joint ventures and provision of ANS related services on a commercial basis. The data (presented in section 4) indicate that ownership or co-ownership of commercially oriented subsidiaries or joint ventures is the most frequently exercised way of providing commercial services by ANSPs. $82 \%$ of all ANSPs showing signs of commercialisation own or co-own at least one subsidiary or joint venture. Subsidiaries are often engaged in commercial activities in national markets, but they are also used as a "penetrating tool" for entering new markets. ANSPs with a well-developed portfolio of commercial activities often own or co-own one subsidiary, which they use to manage and administer other ventures belonging to the company's portfolio (e.g. DFS International Business Services or NATS Services). Joint ventures are also used to carry out commercial activities. This method of cooperation is most frequently exercised by ANSPs when they are starting activities with high initial costs: e.g. development and implementation of new technologies. Services or products of these joint ventures are usually offered on international markets.

ANS related commercial services (products) and development of innovative technologies are the most common commercial activities of ANSPs in terms of scope. Many smaller ANSPs demand outsourced ANS related services (e.g. training of ATCOs or calibrating services). One of the reasons for outsourcing is cost reduction and technical 
complexity of the activities that ANSPs would not be able to manage on their own. On the other hand, large air navigation service providers, which have extensive experience in such tasks, offer them on a commercial basis. Provision of such activities enables them to penetrate the market as it does not require introduction of deregulated legislative framework.

The least frequent commercial product offered by ANSPs is provision of ANS on a commercial (deregulated) basis. The reason is that many markets keep on protecting their national providers and these markets have not been deregulated. Markets that provide ANS have not been fully liberalised across Europe which means that there is a very limited number of opportunities for ANSPs to enter international markets.

This research shows that liberalisation of national markets with the provision of ANS has a positive impact on commercialisation of the industry. The "TOP 4" most commercialised ANSPs (sorted by $\mathrm{A}_{\mathrm{CI}}$ ) offer their services in partially de-regulated (liberalised) national markets with ANS. This fact indicates that the presence of the competition in national markets has a positive impact on commercialisation of ANSPs.

The authors of this research understand that there are several additional aspects of commercialisation of ANSPs that would be worth exploring in future research. First of all, there is the impact of commercialisation of ANSPs on their financial performance and cost-effectiveness. The authors are currently unable to conduct such a research as the consistent economic data (that the research is strongly dependent on) is not available and the data from annual reports provide only a fragmented view on the issue. The authors hope that the situation will improve with the introduction of Reference Period (RP3) and that future research of the impact of commercialisation on the financial performance of air navigation services providers will become possible, which will allow us to get more refined results of the commercialisation index. Secondly, memberships in international research projects such as Horizon or SESAR are also worth exploring. However, at the time of conducting this research it was merely impossible to distinguish between commercially oriented and only research focused projects.
However, the question for now is how ANSPs will be exercising the legislative requirement for reporting their commercial revenues and how consistent the data will be for further research.

\section{ACKNOWLEDGEMENTS}

This paper was supported by the project VEGA 1/0695/21 Air Transport and COVID-19: Research of the crisis impacts with a focus on the possibilities to revitalise the industry, which is financed by Ministry of Education, Science, Research and Sport of the Slovak Republic.

Ing. MATÚŠ MATERNA, PhD. ${ }^{1}$

E-mail: matus.materna@fpedas.uniza.sk

doc. Ing. BENEDIKT BADÁNIK, PhD. ${ }^{1}$

E-mail: benedikt.badanik@fpedas.uniza.sk doc. JUDr. Ing. ALENA NOVÁK SEDLÁČKOVÁ, PhD. ${ }^{1}$ E-mail: alena.sedlackova@fpedas.uniza.sk Ing. ANDREA MATERNOVÁ, PhD. ${ }^{2}$

E-mail: andrea.galierikova@ffpedas.uniza.sk

${ }^{1}$ Katedra leteckej dopravy

Fakulta prevádzky a ekonomiky dopravy a spojov

Žilinská univerzita v Žiline

Univerzitná 1, 01026 Žilina, Slovenská republika

${ }^{2}$ Katedra vodnej dopravy

Fakulta prevádzky a ekonomiky dopravy a spojov

Žilinská univerzita v Žiline

Univerzitná 1, 01026 Žilina, Slovenská republika

\section{KOMERCIALIZÁCIA POSKYTOVATELOV LETECKÝCH NAVIGAČNÝCH SLUŽIEB - AKTUÁLNY STAV VEURÓPE}

\section{ABSTRAKT}

Tento článok popisuje súčasný stav komercializácie poskytovatel'ov leteckých navigačných služieb (LNS) v Európe. Prehl'adným spôsobom mapuje podobný výskum $z$ oblasti komercializácie poskytovatelov LNS a identifikuje jej dva základné externé faktory - liberalizáciu národných trhov a dopyt po d'alšich službách súvisiacich s LNS. V článku navrhujeme metodiku numerického hodnotenia stupňa komercializácie na základe indexu komercializácie poskytovatelov LNS (indexu $A_{C V}$ ) a predstavujeme numerické hodnotenie indexu $A_{C I} 35 \mathrm{eu}$ rópskych poskytovatelov. Zároveň kategorizujeme poskytovatelov do šiestich rôznych kategórií, ktoré odrážajú rôzny stupeň ich komercializácie. Výsledky ukazujú, že 63\% európskych poskytovatel'ov LNS vykazuje známky komercializácie. Potvrdilo sa tiež, že korporatizáciu nemožno považovat' za priamy prejav komercializácie. Napriek prevládajúcemu názoru, že korporatizovaní poskytovatelia sú komerčne aktívni, zistenia ukazujú, že takmer 40\% korporatizovaných európskych poskytovatelov LNS nie je komerčne aktívnych. Náš článok tiež uvádza, že dominantným prejavom komercializácie 
je napr. vlastnictvo dcérskych spoločností a spoločných podnikov. Naše výsledky tiež ukazujú, že poskytovanie a rozvoj komerčných služieb a produktov súvisiacich s LNS sú najbežnejšimi obchodnými činnostami európskych poskytovatel'ov leteckých navigačných služieb.

\section{KLÚČOVÉ SLOVÁ}

komercializácia; poskytovatelia leteckých navigačných služieb; prevádzkový model.

\section{REFERENCES}

[1] Majumdar A. Commercializing and restructuring air traffic control: A review of the experience and issues involved. Journal of Air Transport Management. 1995;2(2): 112122. DOI: 10.1016/0969-6997(96)00004-X

[2] Golaszewski R. Reforming air traffic control: An assessment from the American perspective. Journal of Air Transport Management. 2002;8(1): 3-11. DOI: 10.1016/ S0969-6997(01)00018-7

[3] Goodliffe M. The new UK model for air traffic services A public private partnership under economic regulation. Journal of Air Transport Management. 2002;8(1): 13-18. DOI: 10.1016/S0969-6997(01)00029-1

[4] Button K, McDougall G. Institutional and structure changes in air navigation service-providing organizations. Journal of Air Transport Management. 2006;12(5): 236-252. DOI: 10.1016/j.jairtraman.2006.07.001

[5] Dempsey PS, et al. The Mcgill Report on Governance of Commercialized Air Navigation Services. Annals of Air and Space Law. 2006;31: 136. Available from: https:// ssrn.com/abstract=2699287 [Accessed 14th June 2021].

[6] Steuer M. The partially private UK system for air traffic control. Journal of Air Transport Management. 2010;16(1): 26-35. DOI: 10.1016/j.jairtraman.2009.07.011

[7] McDougall G, Roberts AS. Commercializing Air Traffic Control: Have the Reforms Worked? Canadian Public Administration. 2007;51(1): 45-69. DOI: 10.1111/j.17547121.2008.00004.x

[8] Jones A, Guthrie J. Protecting 'Public Interest' in Modernised Skies. In: The $5^{T H}$ International Conference on Accounting, Auditing \& Management in Public Sector Reforms, 3-5 September 2008, Amsterdam, Netherlands; 2009. p. 31. Available from: https://papers.ssrn.com/ sol3/papers.cfm?abstract_id=1358703 [Accessed 14th March 2021].

[9] Novák A, Pitor J. Flight inspection of instrument landing system. In: 2011 IEEE Forum on Integrated and Sustainable Transportation Systems, FISTS 2011, 29 June-1 July 2011, Vienna, Austria; 2011. p. 329-332. DOI: 10.1109/ FISTS.2011.5973617

[10] Novák A. Wind farms and aviation. Aviation. 2009;13(2): 56-59. DOI: $10.3846 / 1648-7788.2009 .13 .56-59$

[11] Tomová A. The need for new directions in airspace economics: Seventy years after Chicago. Journal of Air Transport Management. 2015;44-45: 1-7. DOI: 10.1016/j.jairtraman.2015.01.005

[12] Tomová A. Are commercial revenues important to today's European air navigation service providers?
Journal of Air Transport Management. 2016;54: 80-87. DOI: 10.1016/j.jairtraman.2016.03.023

[13] Tomová A. Two businesses of air navigation service providers: The case study of NATS. Transportation Research Procedia. 2017;28: 99-105. DOI: 10.1016/j.trpro.2017.12.173

[14] Bartoš M, Badánik B. Competitive challenges facing the air navigation services in Europe. AEROjournal. 2019;2: 19-24. DOI: 26552/aer.C.2019.2

[15] Dempsey-Brench Z, Volta N. A cost-efficiency analysis of European air navigation service providers. Transportation Research Part A: Policy and Practice. 2018;111: 11-12. DOI: $10.1016 /$ j.tra.2018.02.019

[16] Buyle S, Dewulf W, Kupfer F, Onghena E, Meersman H, de Voorde EV. From traditional to professional Air Navigation Service Provider: A typology of European ANSP business models. Journal of Air Transport Management. 2021;91. DOI: 10.1016/j.jairtraman.2020.102006

[17] Wirsamulia F. Comercialization of Airnav Indonesia as Air Navigation Provider: Is it beneficial? Jurnal Media Hukum. 2019;27(1): 133-146. DOI: 10.18196/ jmh.2020014

[18] ICAO. Case Studies on Commercialization, Privatization and Economic Oversight of Airports and Air Navigation Services Providers (ANSPS). International Civil Aviation Organization; 2013. Available from: https:// www.icao.int/sustainability/pages/Eap_ER_Databases_CaseStudies_ANSPs.aspx [Accessed 6th June 2021].

[19] IATA. Commercialisation of Air Navigation Service Providers. International Air Transport Association; 2011. Available from: https://www.iata.org/contentassets/4eae6e82b7b948b58370eb6413bd8d88/commercialisation-ansps.pdf [Accessed 5th June 2021].

[20] ATM Policy Institute. The case for liberalising air traffic control. The ATM Policy Institute; 2017. Available from: https://www.atmpolicy.aero/2017/01/27/the-case-for-liberalising-air-traffic-control/ [Accessed 7th June 2021].

[21] Benderli G, Smith P. Could Air Traffic Management learn from other network industries? Association for European Transport; 2006. Available from: https://www.researchgate.net/publication/237552859 COULD AIR TRAFFIC_MANAGEMENT_LEARN_FROM_OTHER_ NETWORK_INDUSTRIES [Accessed 14th June 2021].

[22] McMillan D. Cleared for take off. Airspace 39. 2017;4. Available from: https://issuu.com/canso/docs/airspace_39_quarter_4_2017_150dpi_[Accessed 7th June 2021].

[23] HELIOS. Study into Air Navigation Services to be opened to competition in Norway: Part 1. HELIOS; 2015. Available from: https://www.regjeringen.no/contentassets/991dbf53e1b74ccea64a4d37331c5574/studyinto-air-navigation-services-to-be-opened-to-competition-in-norway-final-report-part-1.pdf [Accessed 14th June 2021].

[24] HELIOS. Study into Air Navigation Services to be opened to competition in Norway: Part 2. HELIOS; 2016. Available from: https://www.regjeringen.no/contentassets/54ed74c1221a4a4c8a46ee74b84bc393/studyinto-air-navigation-services-to-be-opened-to-competition-in-norway-final-report-part-2.pdf [Accessed 14th June 2021]. 
[25] Materna M, Galierková A. A new approach to classification of air navigation service providers in the context of commercialization. In: Transportation Research Procedia 43, $8^{\text {th }}$ International Conference on Air Transport, INAIR 2019, 12-13 November 2019, Hainburg an der Donau, Austria; 2019. p. 139-146. DOI: 10.1016/j.trpro. 2019.12.028

[26] Materna M. Variants of air navigation service providers' business models. In: Transportation Research Procedia 40, $13^{\text {th }}$ International Scientific Conference on Sustain- able, Modern and Safe Transport, TRANSCOM 2019, 29-31 May 2019, Vysoké Tatry, Slovakia; 2019. p. 11271133. DOI: 10.1016/j.trpro.2019.07.157

[27] Materna M, Galieriková A, Palčák M. Reflection of commercialization in organizational and ownership structure of Deutsche Flugsicherung GmbH (DFS). In: Transportation Research Procedia 51, $9^{\text {th }}$ International Conference on Air Transport, INAIR 2020, 4-5 November 2020, Žilina, Slovakia; 2020. p. 283-292. DOI: 10.1016/j.trpro. 2020.11.031 